
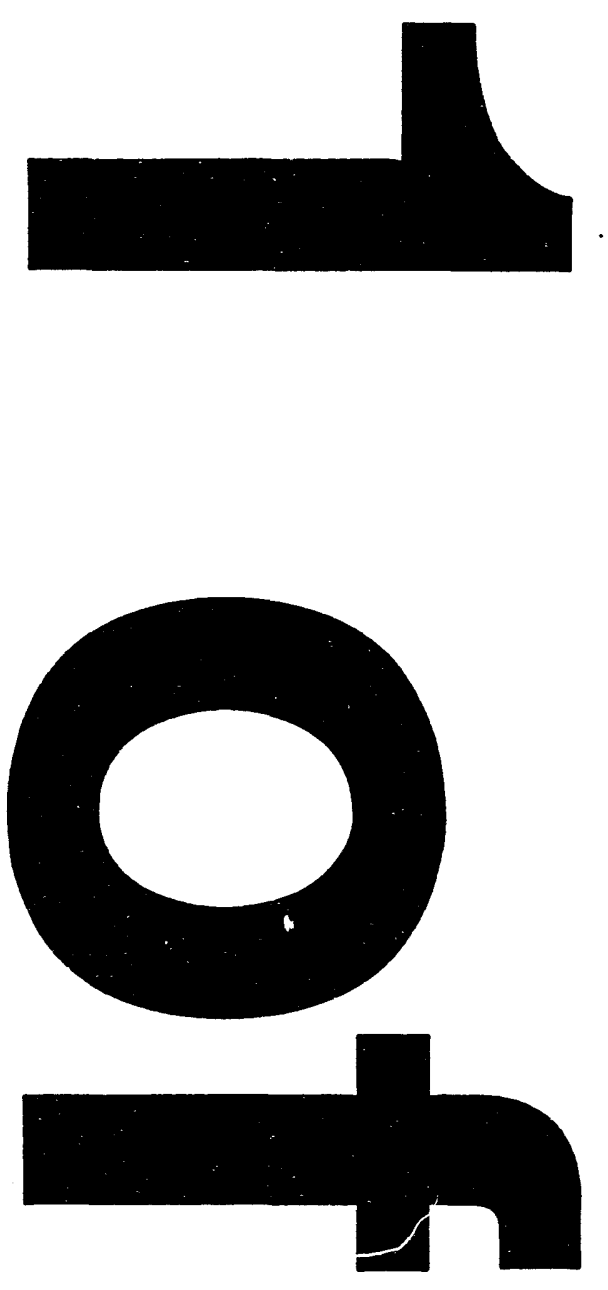

!

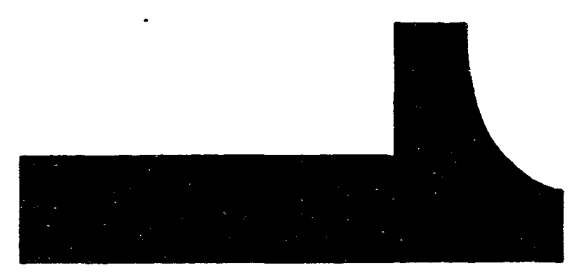




\title{
Characterization of Analytical Reference Glass-1 (ARG-1)
}

\author{
G. L. Smith
}

December 1993

Prepared for

the U.S. Department of Energy

under Contract DE-AC06-76RLO 1830

Pacific Northwest Laboratory

Richland, Washington 99352 


\section{Summary}

High-level radioactive waste may be immobilized in borosilicate glass. Before disposing of this glass in a geologic repository, waste form producers must report the measured chemical composition of the vitrified waste according to the U. S. Department of Energy's Waste Acceptance Product Specifications. To help meet this requirement, the Pacific Northwest Laboratory acquires and distributes appropriate nuclear-waste-related standard analytical reference materials. Use of common analytical reference materials will allow the waste glass producers' analytical laboratories to calibrate instrumentation and check procedures. Analytical Reference Glass - 1 (ARG-1) is one such standard. This document reports the chemical analyses and characterization of ARG-1. When new data on ARG-1 are generated, this document will be revised. 


\section{Acknowledgments}

This author gratefully acknowledges the help of N. E. Bibler and C. M. Jantzen of the Savannah River Technology Center and H. D. Smith of Pacific Northwest Laboratory for help in gathering data on the pre-ARG-1 material (DWPF startup frit) and AGR-1, respectively; the help of Linda Adams of CELS - Corning Laboratory Services and Steve Wilson of the USGS, Denver, Colorado, for supplying chemical analysis data. 


\section{Contents}

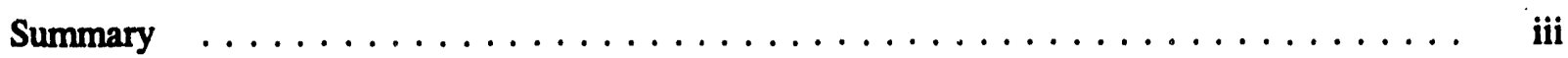

Acknowledgments $\ldots \ldots \ldots \ldots \ldots \ldots \ldots \ldots \ldots \ldots \ldots \ldots \ldots \ldots \ldots$

1.0 Introduction $\ldots \ldots \ldots \ldots \ldots \ldots \ldots \ldots \ldots \ldots \ldots \ldots \ldots \ldots \ldots \ldots$

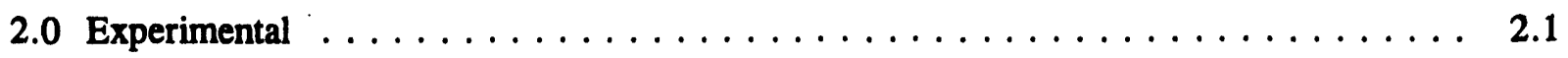

2.1 Glass Fabrication $\ldots \ldots \ldots \ldots \ldots \ldots \ldots \ldots \ldots \ldots \ldots \ldots \ldots \ldots$

2.2 Glass Sampling $\ldots \ldots \ldots \ldots \ldots \ldots \ldots \ldots \ldots \ldots \ldots \ldots \ldots \ldots \ldots$

2.3 Glass Composition Analyses $\ldots \ldots \ldots \ldots \ldots \ldots \ldots \ldots \ldots \ldots \ldots$

2.4 Glass Homogeneity Analyses $\ldots \ldots \ldots \ldots \ldots \ldots \ldots \ldots \ldots \ldots \ldots$

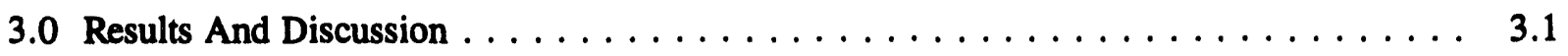

3.1 Glass Composition Analyses $\ldots \ldots \ldots \ldots \ldots \ldots \ldots \ldots \ldots \ldots \ldots \ldots \ldots$

3.2 Glass Homogeneity Analyses $\ldots \ldots \ldots \ldots \ldots \ldots \ldots \ldots \ldots \ldots \ldots \ldots$

4.0 Conclusions $\ldots \ldots \ldots \ldots \ldots \ldots \ldots \ldots \ldots \ldots \ldots \ldots \ldots \ldots \ldots \ldots \ldots$

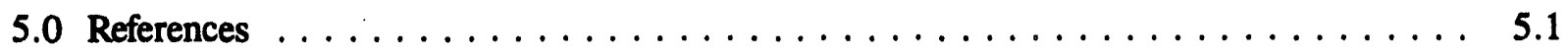

Appendix A - CELS - Corning Laboratory Services Chemical Analysis of Analytical Reference Glass-1 (ARG-1) 


\section{Tables}

2.1 Savannah River Product Specification for Manufacture of the DWPF

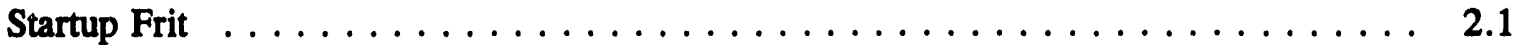

3.1 Comparison of the Target and Analyzed Analytical Reference Glass-1

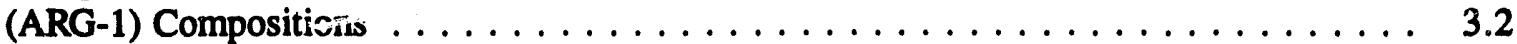




\subsection{Introduction}

High-level radioactive waste may be immobilized in borosilicate glass at the West Valley Demonstration Project, West Valley, New York, the Defense Waste Processing Facility (DWPF), Aiken, Scuth Carolina, and the Hanford Waste Vitrification Project (HWVP), Richland, Washington. The vitrified waste form will be stored in stainless steel canisters before its eventual transfer to a geologic repository for long-term disposal. Waste Acceptance Product Specifications (WAPS) (DOE 1993), Section 1.1.2 requires that the waste form producers must report the measured chemical composition of the vitrified waste in their production records before disposal.

Chemical analysis of glass waste forms is receiving increased attention due to qualification requirements of vitrified waste forms. The Pacific Northwest Laboratory (PNL) ${ }^{(a)}$ has been supporting the glass producers' analytical laboratories by a continuing program of multilaboratory analytical testing using interlaboratory "round robin" methods (Smith and Marschman, in press). At the PNL Materials Characterization Center Analytical Round Robin 4 workshop "Analysis of Nuclear Waste Glass and Related Materials," January 16-17, 1990, Pleasanton, California, the meeting attendees decided that simulated nuclear waste analytical reference glasses were needed for use as analytical standards. Use of common standard analytical reference materials would allow the glass producers' analytical laboratories to calibrate procedures and instrumentation, to control laboratory performance and conduct selfappraisals, and to help qualify their various waste forms.

Based on recommendations and discussions from that workshop, it was decided that Analytical Reference Glass - 1 (ARG-1) would consist of approximately $110 \mathrm{~kg}$ of Defense Waste Processing Facility (DWPF) simulated waste glass frit. This reference glass would need to be a homogeneous material with accurately known chemical composition, but leaching characteristics would not be relevant since this glass would be used only as an analytical standard and not as a leaching standard. The ARG-1 glass $^{(b)}$ contains the more commonly measured elements in all proposed nuclear waste glass form compositions.

(a) Pacific Northwest Laboratory is operated for the U.S. Department of Energy by Battelle Memorial Institute under Contract DE-AC06-76RLO 1830.

(b) Available from K. M. Olson, Materials Characterization Center, Pacific Northwest Laboratory. 


\subsection{Experimental}

\subsection{Glass Fabrication}

The DWPF startup frit was manufactured by the Ferro Corporation for the Savannah River Laboratory (Jantzen 1989). Ferro Corporation was asked to batch the black frit to the Savannah River product oxide specification shown in Table 2.1. The glass was fabricated in a gas fired refractory smelter at a temperature of $1315^{\circ} \mathrm{C}$. The glass melt was roll quenched into sheets that were processed through a finger crusher and hammer mill into a "corn flake" size consistency. The "corn flake" sized glass was then processed in a Kennedy Van Saun ceramic-lined continuous ball mill and sieved to a -80 to +200 mesh particle size. Fines were reprocessed in the smelter, and the larger particles were remilled. Approximately 15,000 pounds of black frit was produced, corresponding to Ferro Corporation product number SG-565.

\subsection{Glass Sampling}

Approximately $110 \mathrm{~kg}$ of DWPF startup frit from Lot \#10-27-87 was shipped to Corning Incorporated in a single container. Corning ground and sieved the frit to -100 mesh and then blended the entire sample. The crushed and blended frit was then repackaged into three drums. A metal tube of $\sim 1 / 2$ in. diameter was used to sample each of the three drums near the bottom and top to make up the six samples used for chemical analyses. Upon receipt of the $110+\mathrm{kg}$ of powdered ARG-1 glass from Corning, PNL repackaged it into $1-\mathrm{kg}$ lots for shipment. In addition to the sampling and analysis done by CELS - Corning Laboratory Services, PNL used ARG-1 as an unknown in Nuclear Waste Analytical Round Robin 6. For this round robin, each participating laboratory was given two 5-g samples of

Table 2.1. Savannah River Product Specification for Manufacture of the DWPF Startup Frit

\begin{tabular}{lcc} 
Oxide & wt\% \pm wt \% range \\
\cline { 3 - 3 } $\mathrm{SiO}_{2}$ & & $49.0 \pm 1.0$ \\
$\mathrm{Fe}_{2} \mathrm{O}_{3}$ & & $13.5 \pm 1.0$ \\
$\mathrm{Na}_{2} \mathrm{O}$ & $11.5 \pm 1.0$ \\
$\mathrm{~B}_{2} \mathrm{O}_{3}$ & & $8.8 \pm 1.0$ \\
$\mathrm{Li}_{2} \mathrm{O}$ & $3.5 \pm 0.5$ \\
$\mathrm{Al}_{2} \mathrm{O}_{3}$ & & $4.7 \pm 1.0$ \\
$\mathrm{MnO}_{2}$ & $2.3 \pm 0.5$ \\
$\mathrm{CaO}$ & $1.2 \pm 0.5$ \\
$\mathrm{NiO}$ & $1.1 \pm 0.5$ \\
$\mathrm{MgO}$ & $0.7 \pm 0.5$ \\
$\mathrm{~K}_{2} \mathrm{O}$ & $2.6 \pm 0.5$ \\
$\mathrm{TiO}_{2}$ & $1.0 \pm 0.5$ \\
$\mathrm{Cr}_{2} \mathrm{O}_{3}$ & $0.1 \pm 0.05$ \\
& & \\
$\mathrm{Sum}$ & &
\end{tabular}


ARG-1. The first sample was representative of a 1-kg lot of ARG-1. The second sample was representative of a composite sample made up of more than twenty $10-\mathrm{g}$ samples taken from every fifth $\mathrm{kg}$ while the $110+\mathrm{kg}$ of ARG-1 was being repackaged into 1-kg lots.

\subsection{Glass Composition Analyses}

CELS - Corning Laboratory Services analyzed six samples of ARG-1, which were selected randomly from the ground and blended glass. Each glass sample was dissolved in triplicate (18 replicates) with each replicate read twice independently to ensure that the two values corresponded closely (these duplicate reads are designated $\mathrm{a}$ and $\mathrm{b}$ in Appendix $\mathrm{A}$ ). Details of the procedures used by Corning to analyze ARG-1 are given by C. M. Jantzen et al. (1993).

Samples of ARG-1 (see Glass Sampling above) were analyzed by seven different laboratories in Nuclear Waste Analytical Round Robin 6. A number of different sample preparations and analytical methods were used in the chemical analysis of ARG-1. In these cases ARG-1, was sent out to the Round Robin 6 participants as an unknown.

Three 5-g samples of ARG-1 were sent to the United States Geological Survey (USGS) for analysis in conjunction with Nuclear Waste Analytical Round Robin 7. The samples were chemically analyzed using both wavelength-dispersive $x$-ray fluorescence (WDXRF) and inductively coupled plasma atomic emission spectroscopy (ICP-AES). The WDXRF and ICP-AES data precision and accuracy were excellent and therefore are included in this report to compare with the Corning data. Both Corning and the USGS had nominal composition data before the analyses.

\subsection{Glass Homogeneity Analyses}

Three techniques were used to determine glass powder sample homogeneity: transmitted light optical microscopy based on color distribution and glass grain characteristics; scanning electron microscopy (SEM) analysis using energy dispersive analysis by $\mathrm{x}$-ray (EDAX) of about 100 individual glass grains; and collection of chemical analysis data on random glass samples (see Glass Sampling above). 


\subsection{Results And Discussion}

\subsection{Glass Composition Analyses}

The mean wt \% and standard deviations of the 18 replicate ARG-1 glass analyses (Appendix A) measured by CELS - Corning Laboratory Services are given in Table 3.1. The nominal composition shown in Table 3.1 is chemical composition data provided by Savannah River Laboratory. These data were given to Corning before their chemical analyses.

Table 3.1 also lists the mean wt \% and standard deviations for the USGS analyses obtained using WDXRF and ICP-AES. The USGS WDXRF group prepared working discs for three samples from a single bottle. The discs were counted at three different times over the course of two days. The USGS was provided with the Corning data as the nominal composition before their analyses.

The mean wt\% and total standard deviations for the laboratories that participated in Round Robin 6 are also reported in Table 3.1, along with the number of laboratories whose data contributed to the mean wt\% value reported for each oxide. Each laboratory analyzed ARG-1 as an unknown. It was found that in almost all cases, the interlaboratory variability is higher than the intralaboratory variability. The total standard deviations reported for Round Robin 6 were calculated from the data reported by each laboratory and are in most cases higher than the standard deviations reported by an individual laboratory. Comparison of the data in Table 3.1 gives a good representation of the quality of data to be expected when the sample being analyzed is an unknown. Standard deviations associated with the interlaboratory data are representative of data reported in other round robins.

The ferrous/ferric ratio in Table 3.1 listed under the Round Robin 6 data is the mean of three analyses performed at Pacific Northwest Laboratory. The redox measurement method used was a calorimetric 1, 10-phenanthroline procedure (Hara 1992). The standard deviation was calculated from three different measurements. The redox value reported by the USGS is also the mean of three analyses and the calculated standard deviation.

\subsection{Glass Homogeneity Analyses}

Transmitted light optical microscopy observations showed that the entire lot of ARG-1 was homogeneous on the basis of the color distribution and glass grain characteristics. Optical microscopy observation showed that most grains were brown although a few were colorless. Use of index matching fluid showed that the brown grains had an index of refraction, $D$, approximately equal to 1.6. The colorless glass grains had a different index of refraction, but this was not measured. Some glass grains showed striations, very small dark inclusions, or very small bubbles. An extremely small fraction of grains, $\leqslant 1 \%$, appeared to be a crystalline phase.

In conjunction with EDAX, SEM was used to characterize this possible crystalline phase. The SEM observations did not conclusively show that the phase was crystalline, but found the phase high in aluminum. The phase was thought to be alumina from the alumina ball mill used to grind up the initial DWPF frit. However, this phase is an extremely small portion of the ARG-1 powder and is very evenly distributed throughout the sample. 
Table 3.1. Comparison of the Target and Analyzed Analytical Reference Glass-1 (ARG-1) Compositions

\begin{tabular}{|c|c|c|c|c|c|c|c|c|}
\hline \multirow[b]{2}{*}{ Oxide } & \multirow{2}{*}{$\frac{\begin{array}{c}\text { Nominal } \\
\text { Composition }\end{array}}{w t \%}$} & \multicolumn{2}{|c|}{$\begin{array}{l}\text { Corning Inc. Glass } \\
\text { Composition }\end{array}$} & \multicolumn{2}{|c|}{ USGS Glass Composition } & \multicolumn{3}{|c|}{$\begin{array}{c}\text { MCC Round Robin } 6 \text { Consensus } \\
\text { Glass Composition } \\
\end{array}$} \\
\hline & & $\begin{array}{l}\text { Mean } \\
\text { wt\% }\end{array}$ & SD & $\begin{array}{l}\text { Mean wt\% } \\
\text { WDXRF/ICP } \\
\end{array}$ & SD WDXRF/ICP & $\begin{array}{c}\# \\
\text { Labs } \\
\end{array}$ & $\begin{array}{c}\text { Mean } \\
\text { wt\% }\end{array}$ & $\begin{array}{c}\text { Total } \\
\text { SD } \\
\end{array}$ \\
\hline $\mathrm{Al}_{2} \mathrm{O}_{3}$ & 4.53 & 4.73 & 0.022 & $4.60 / 4.66$ & $0.016 / 0.031$ & 7 & 4.66 & 0.152 \\
\hline $\mathrm{B}_{2} \mathrm{O}_{3}$ & 8.39 & 8.67 & 0.040 & $-/ 8.41$ & $--/ 0.069$ & 7 & 8.54 & 0.344 \\
\hline $\mathrm{BaO}$ & 0.04 & 0.088 & 0.001 & -10.087 & -10.001 & 6 & 0.09 & 0.01 \\
\hline $\begin{array}{l}\mathrm{BeO} \\
\mathrm{CaO}\end{array}$ & & & & -10.006 & $-1<0.0005$ & & & \\
\hline $\begin{array}{l}\mathrm{CaO} \\
\mathrm{CeO}_{2}\end{array}$ & 1.53 & 1.43 & 0.009 & $1.43 / 1.43$ & $0.003 / 0.015$ & 7 & 1.42 & 0.055 \\
\hline $\begin{array}{l}\mathrm{CeO}_{2} \\
\mathrm{CoO}\end{array}$ & & & & -10.004 & $-1<0.0005$ & & & \\
\hline $\begin{array}{l}\mathrm{CoO} \\
\mathrm{Cr}_{2} \mathrm{O}_{3}\end{array}$ & & & & -10.005 & $--/ 0.001$ & & & \\
\hline $\begin{array}{l}\mathrm{Cr}_{2} \mathrm{O}_{3} \\
\mathrm{CuO}\end{array}$ & 0.096 & 0.093 & 0.001 & $0.09 / 0.106$ & $<0.005 / 0.001$ & 7 & 0.10 & 0.010 \\
\hline $\begin{array}{l}\mathrm{CuO} \\
\mathrm{Fe}_{2} \mathrm{O}_{3}\end{array}$ & 0.008 & 0.004 & 0.000 & -10.004 & $-1<0.0005$ & 5 & 0.01 & 0.009 \\
\hline $\mathrm{Fe}_{2} \mathrm{O}_{3}$ & 13.85 & 14.0 & 0.073 & $13.9 / 14.2$ & $0.021 / 0.047$ & 7 & 14.02 & 0.439 \\
\hline $\mathrm{K}_{2} \mathrm{O}$ & 2.59 & 2.71 & 0.016 & $2.66 / 2.47$ & $0.007 / 0.085$ & 7 & 2.68 & 0.182 \\
\hline $\mathrm{Li}_{2} \mathrm{O}$ & 3.26 & 3.21 & 0.015 & $-/ 3.49$ & -10.073 & 7 & 3.18 & 0.237 \\
\hline $\mathrm{MgO}$ & 0.85 & 0.86 & 0.005 & $0.88 / 0.86$ & $0.009 / 0.005$ & 7 & 0.87 & 0.034 \\
\hline $\mathrm{MnO}_{2}$ & 2.39 & 2.31 & 0.012 & $2.23 / 2.39$ & $0.003 / 0.007$ & 7 & 2.32 & 0.057 \\
\hline $\mathrm{Na}_{2} \mathrm{O}$ & 11.36 & 11.5 & 0.023 & $11.1 /-$ & $0.038 /-$ & 7 & 11.20 & 0.791 \\
\hline NiO & 1.03 & 1.05 & 0.006 & $-/ 1.05$ & -10.004 & 7 & 1.04 & 0.104 \\
\hline $\mathrm{P}_{2} \mathrm{O}_{5}$ & 0.25 & 0.22 & 0.011 & $0.286 / 0.29$ & $0.003 / 0.011$ & 6 & 0.27 & 0.070 \\
\hline $\mathrm{SiO}_{2}$ & 48.6 & 47.9 & 0.157 & $47.21-$ & $0.059 /-$ & 7 & 47.75 & 1.531 \\
\hline SrO & 0.006 & 0.0037 & 0.000 & -10.004 & $-1<0.0005$ & 6 & 0.00 & 0.001 \\
\hline $\mathrm{TiO}_{2}$ & 1.12 & 1.15 & 0.007 & $1.14 / 1.18$ & $0.005 / 0.005$ & 7 & 1.17 & 0.063 \\
\hline $\mathrm{V}_{2} \mathrm{O}_{5}$ & & & & $-/ 0.021$ & $-1<0.0005$ & & & \\
\hline $\mathrm{Y}_{2} \mathrm{O}_{3}$ & & & & -10.001 & $--1<0.005$ & & & \\
\hline $\mathrm{ZnO}$ & 0.014 & 0.02 & 0.000 & -10.02 & $-1<0.0005$ & 6 & 0.02 & 0.010 \\
\hline $\mathrm{ZrO}_{2}$ & 0.128 & 0.13 & $\underline{0.005}$ & & & 7 & 0.14 & 0.019 \\
\hline Sum & 100.04 & $1 \overline{00.08}$ & & N/A & & & 99.48 & \\
\hline $\mathrm{Fe}^{2+} / \mathrm{Fe}^{3+}$ & - & -- & - & 0.057 & 0.001 & & 0.0581 & 0.0002 \\
\hline
\end{tabular}


From SEM observations, it was also found that all grains showed about the same suite of elements, with variations in the $\mathrm{Fe} / \mathrm{Si}$ ratio. Differences in this ratio could reflect differences in the orientation of the surface being analyzed relative to the detector or in lack of compositional homogeneity in the original glass melt or both.

Statistical analysis of the different splits of ARG-1 glass used in Round Robin 6 showed that powdered and mixed -100 mesh samples are homogeneous to well within analytical precision. As shown above, ARG-1 is a homogeneous glass powder and can be used as an analytical standard. 


\subsection{Conclusions}

The chemical analysis values for ARG-1 measured by CELS - Corning Laboratory Services, the USGS, and the MCC's Round Robin 6 participants are all within the total standard deviation values from the round robin data. The nominal composition for ARG-1, to be used until further notice, will be the CELS - Corning Laboratory Services analysis. The $\mathrm{Fe}^{2+} / \mathrm{Fe}^{3+}$ ratio measured at PNL is 0.058 and 0.057 measured at the USGS.

The chemical composition of the approximately $110 \mathrm{~kg}$ of -100 mesh ARG-1 powder and the individually packaged $\sim 1-\mathrm{kg}$ lots were determined to be homogeneous. Although glass grain characteristics varied slightly on a microscopic level, the grains were homogeneously distributed. The ARG-1 glass fabricated by Ferro Corporation and ground, sieved, and blended by CELS - Corning Laboratory Services is suitable as an analytical standard. 


\subsection{References}

Department of Energy (DOE). 1993. Waste Acceptance Product Specifications for Vitrified HighLevel Waste Forms. DOE-DWPD-FY93-0288, Office of Environmental Restoration and Waste Management, Washington, DC.

Hara, F. F. 1992. Iron II and Total Iron Ratio. PNL Procedure No. APSL-02, Revision 0, Pacific Northwest Laboratory, Richland, Washington.

Jantzen, C. M. 1989. Characterization of the Defense Waste Processing Facility (DWPF) Startup Frit. WSRC-RP-89-18, Westinghouse Savannah River Company, Aiken, South Carolina.

Jantzen, C. M., N. E. Bibler, D. C. Beam, C. L. Crawford, and M. A. Pickett. 1993. Characterization of the Defense Waste Processing Facility (DWPF) Environmental Assessment (EA) Glass Standard Reference Material (U). WSRC-TR-92-346, Revision 1, Westinghouse Savannah River Company, Aiken, South Carolina.

Smith, G. L., and S. C. Marschman (in press), "Nuclear Waste Analytical Round Robins 1-6 Summary Report." In Scientific Basis for Nuclear Waste Management XVII. Materials Research Society, Pittsburgh, Pennsylvania. 


\title{
Appendix A
}

\author{
CELS - Corning Laboratory Services \\ Chemical Analysis of Analytical Reference Glass-1 (ARG-1)
}




\section{LABORATORY ANALYSIS REPORT}

CELS Client No.: 14594-004

Exhibit B : Quantitative Chemical Analysis

Semple Description: ARG-1 Sample 1

Lab I.D. No.: 34048

\begin{tabular}{lrrrrrr} 
Element & $1 \mathrm{a}$ & $1 \mathrm{~b}$ & $2 \mathrm{a}$ & $2 \mathrm{~b}$ & $3 \mathrm{a}$ & $3 \mathrm{~b}$ \\
\hline Al203 & 4.71 & 4.73 & 4.73 & 4.73 & 4.75 & 4.76 \\
BaO & 0.088 & 0.087 & 0.087 & 0.087 & 0.087 & 0.086 \\
B203 & 8.62 & 8.67 & 8.66 & 8.68 & 8.70 & 8.72 \\
CaO & 1.43 & 1.43 & 1.43 & 1.43 & 1.43 & 1.43 \\
Cr203 & 0.095 & 0.095 & 0.092 & 0.092 & 0.092 & 0.093 \\
CuO & 0.0035 & 0.0035 & 0.0035 & 0.0035 & 0.0035 & 0.0034 \\
Fe203 & 14.0 & 14.0 & 14.0 & 14.0 & 14.0 & 144 \\
K20 & 2.67 & 2.72 & 2.68 & 2.72 & 2.71 & 2.72 \\
Li20 & 3.20 & 3.23 & 3.20 & 3.23 & 3.20 & 3.23 \\
MgO & 0.85 & 0.85 & 0.85 & 0.85 & 0.85 & 0.85 \\
MnO2 & 2.30 & 2.30 & 2.30 & 2.30 & 2.30 & 2.30 \\
Na20 & 11.5 & 11.4 & 11.5 & 11.5 & 11.5 & 11.5 \\
NiO & 1.05 & 1.04 & 1.04 & 1.04 & 1.04 & 1.04 \\
P205 & 0.22 & 0.22 & 0.24 & 0.23 & 0.23 & 0.21 \\
SiO2 & 47.9 & 47.9 & 48.0 & 47.99 & 48.0 & 48.2 \\
SrO & 0.0036 & 0.0035 & 0.0036 & 0.0036 & 0.0036 & 0.0036 \\
TiO2 & 1.15 & 1.15 & 1.15 & 1.15 & 1.16 & 1.15 \\
ZnO & 0.023 & 0.023 & 0.023 & 0.023 & 0.023 & 0.023 \\
Z I02 & 0.12 & 0.13 & 0.12 & 0.13 & 0.13 & 0.13 \\
TOTAL & 99.97 & 99.96 & 100.10 & 100.11 & 100.17 & 100.44
\end{tabular}




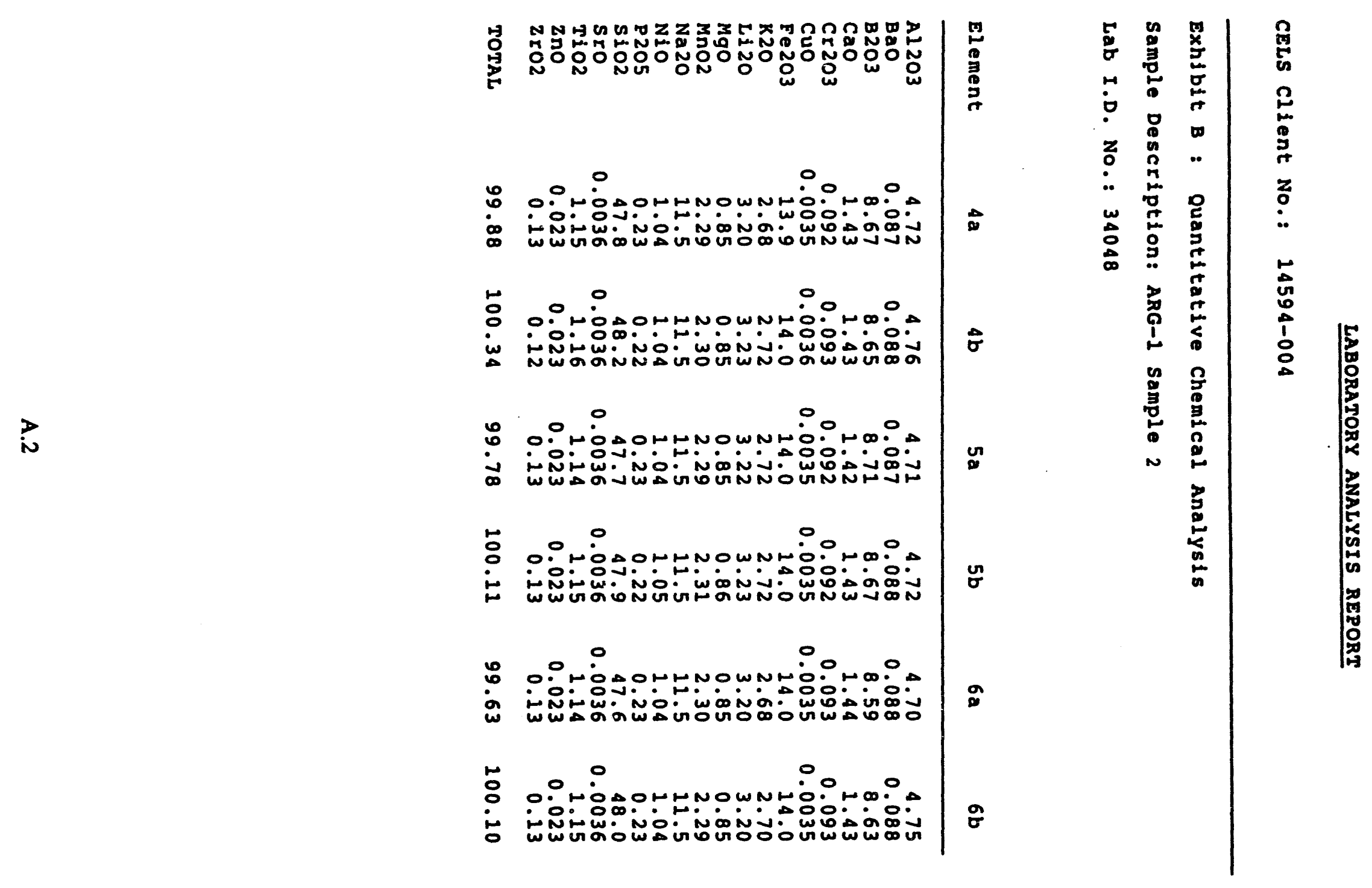



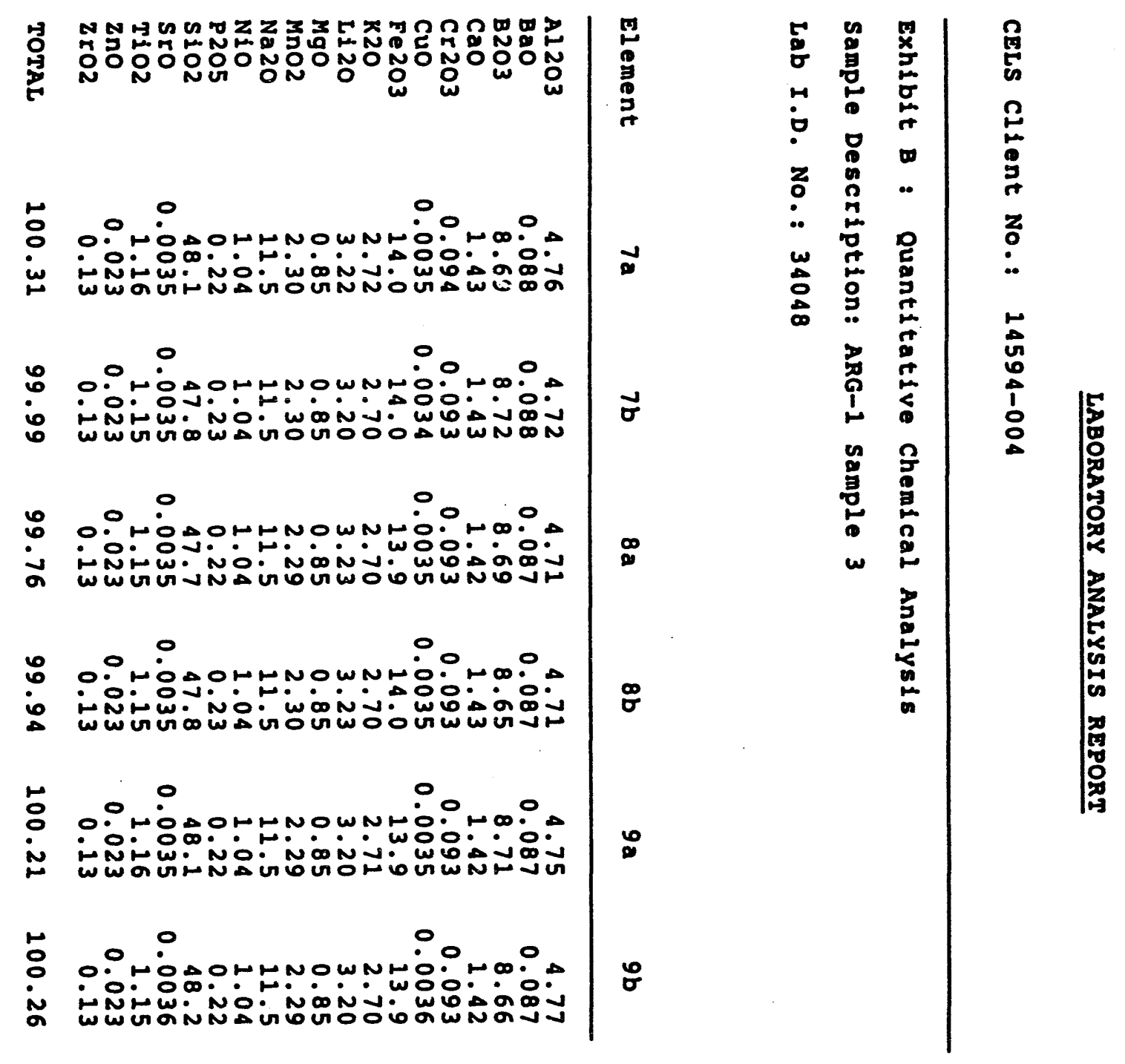


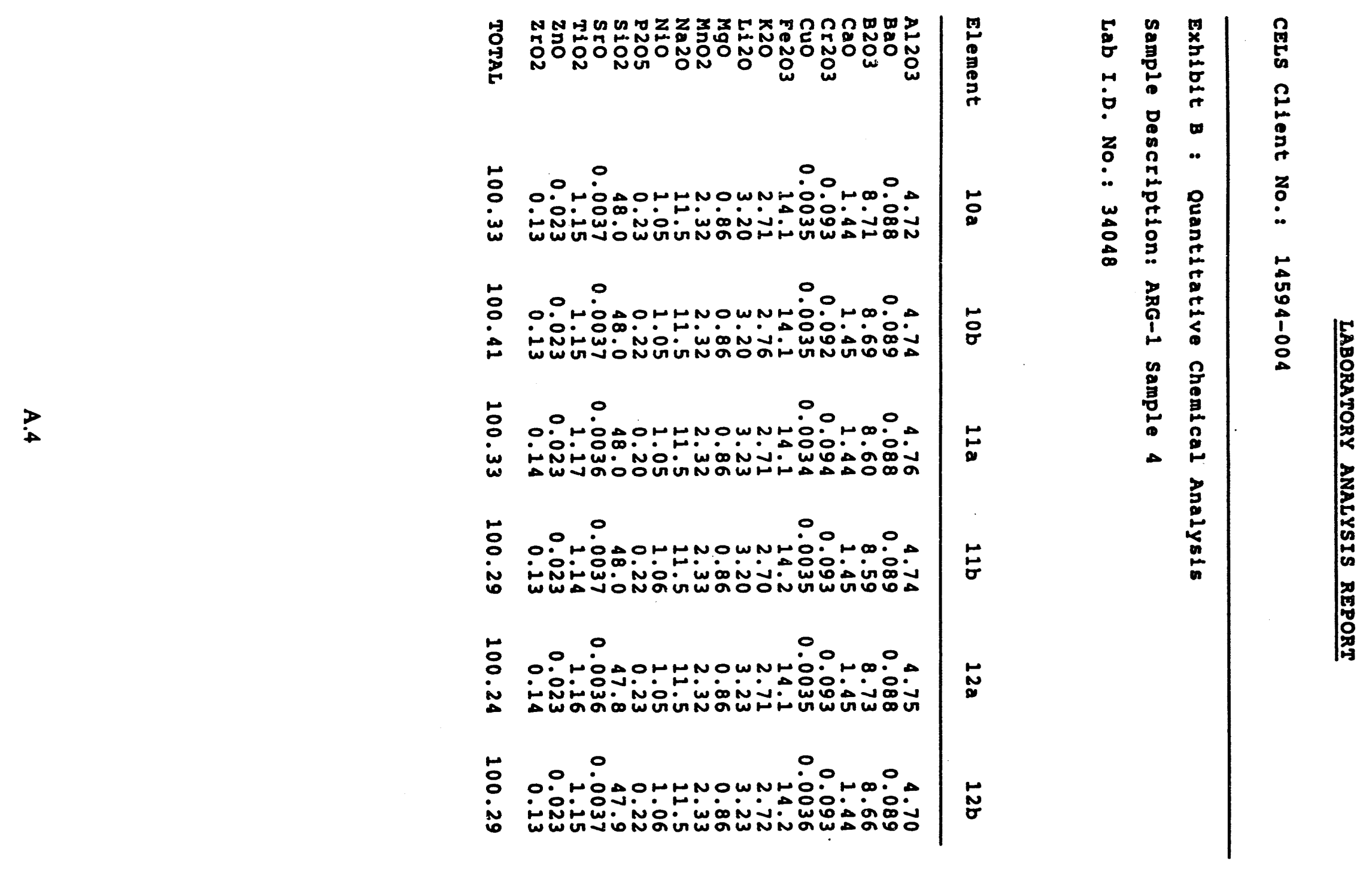




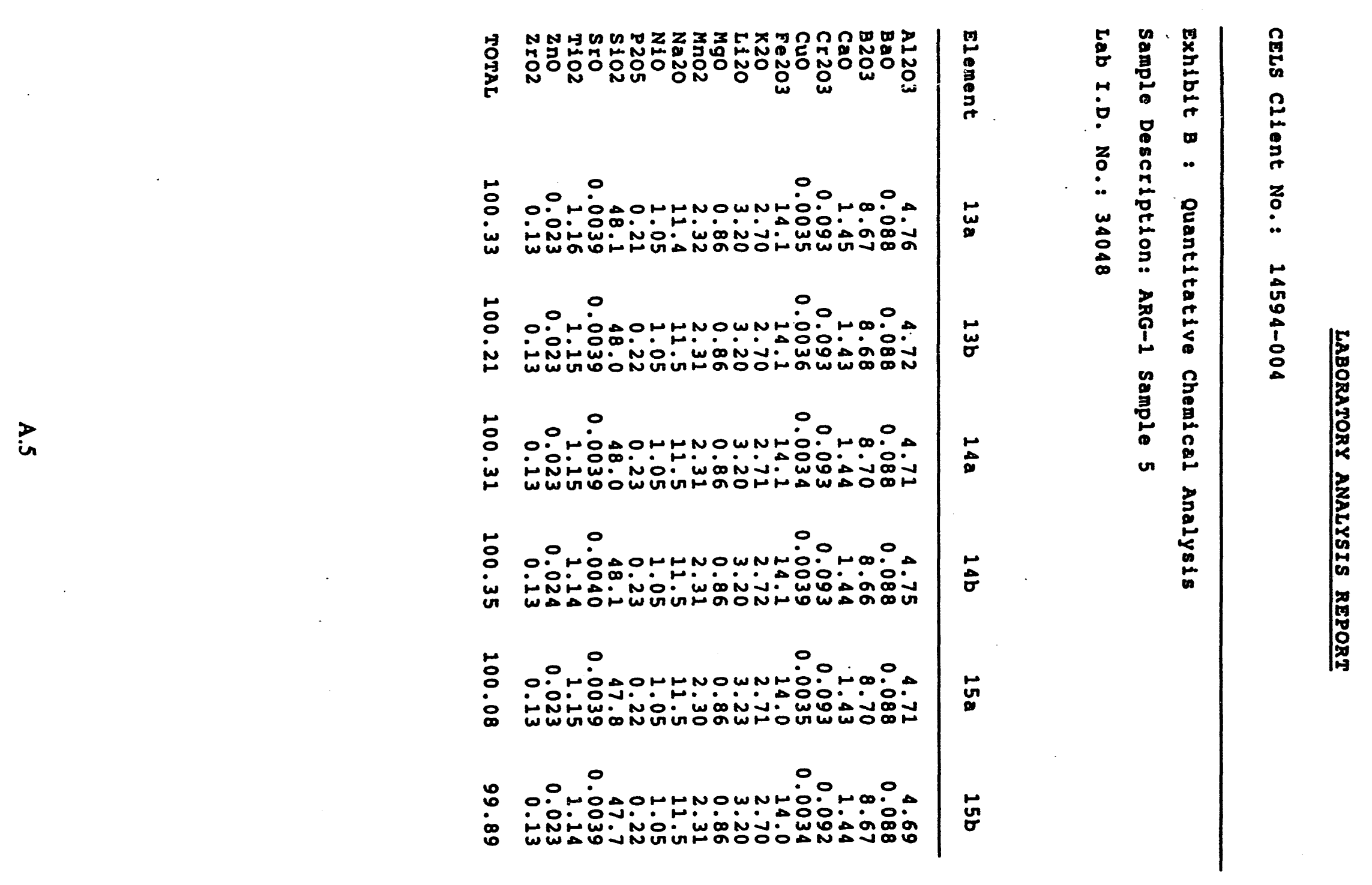




\section{LABORATORY ANALYSIS REPORT}

CELS Client No.: 14594-004

Exhibit B : Quantitative Chemical Analysis

Sample Description: ARG-1 Sample 6

Lab I.D. No.: 34048

\begin{tabular}{lrrrrrr} 
Element & $16 a$ & $16 b$ & $17 a$ & $17 b$ & $18 a$ & $18 b$ \\
\hline Al203 & 4.76 & 4.72 & 4.70 & 4.73 & 4.74 & 4.71 \\
BaO & 0.088 & 0.088 & 0.088 & 0.088 & 0.088 & 0.089 \\
B203 & 8.67 & 8.56 & 8.64 & 8.69 & 8.64 & 8.70 \\
CaO & 1.43 & 1.44 & 1.44 & 1.45 & 1.44 & 1.43 \\
Cr203 & 0.093 & 0.092 & 0.092 & 0.093 & 0.093 & 0.092 \\
CuO & 0.0036 & 0.0036 & 0.0035 & 0.0034 & 0.0036 & 0.0036 \\
Fe203 & 14.1 & 14.1 & 14.1 & 14.1 & 14.1 & 14.0 \\
K20 & 2.72 & 2.70 & 2.73 & 2.72 & 2.72 & 2.70 \\
Li20 & 3.23 & 3.23 & 3.20 & 3.20 & 3.20 & 3.20 \\
MgO & 0.86 & 0.86 & 0.86 & 0.86 & 0.86 & 0.86 \\
MnO2 & 2.30 & 2.32 & 2.31 & 2.31 & 2.32 & 2.31 \\
Na20 & 11.5 & 11.5 & 11.5 & 11.5 & 11.5 & 11.5 \\
NiO & 1.05 & 1.05 & 1.05 & 1.05 & 1.05 & 1.04 \\
P205 & 0.24 & 0.23 & 0.22 & 0.22 & 0.20 & 0.26 \\
S102 & 48.1 & 47.8 & 47.8 & 48.2 & 48.0 & 47.6 \\
SrO & 0.0039 & 0.0040 & 0.0038 & 0.0039 & 0.0039 & 0.0039 \\
TiO2 & 1.16 & 1.14 & 1.15 & 1.16 & 1.15 & 1.15 \\
ZnO & 0.023 & 0.023 & 0.023 & 0.023 & 0.023 & 0.023 \\
ZrO2 & 0.14 & 0.13 & 0.14 & 0.14 & 0.13 & 0.13 \\
TOTAL & 100.37 & 100.03 & 100.07 & 100.55 & 100.25 & 99.81
\end{tabular}



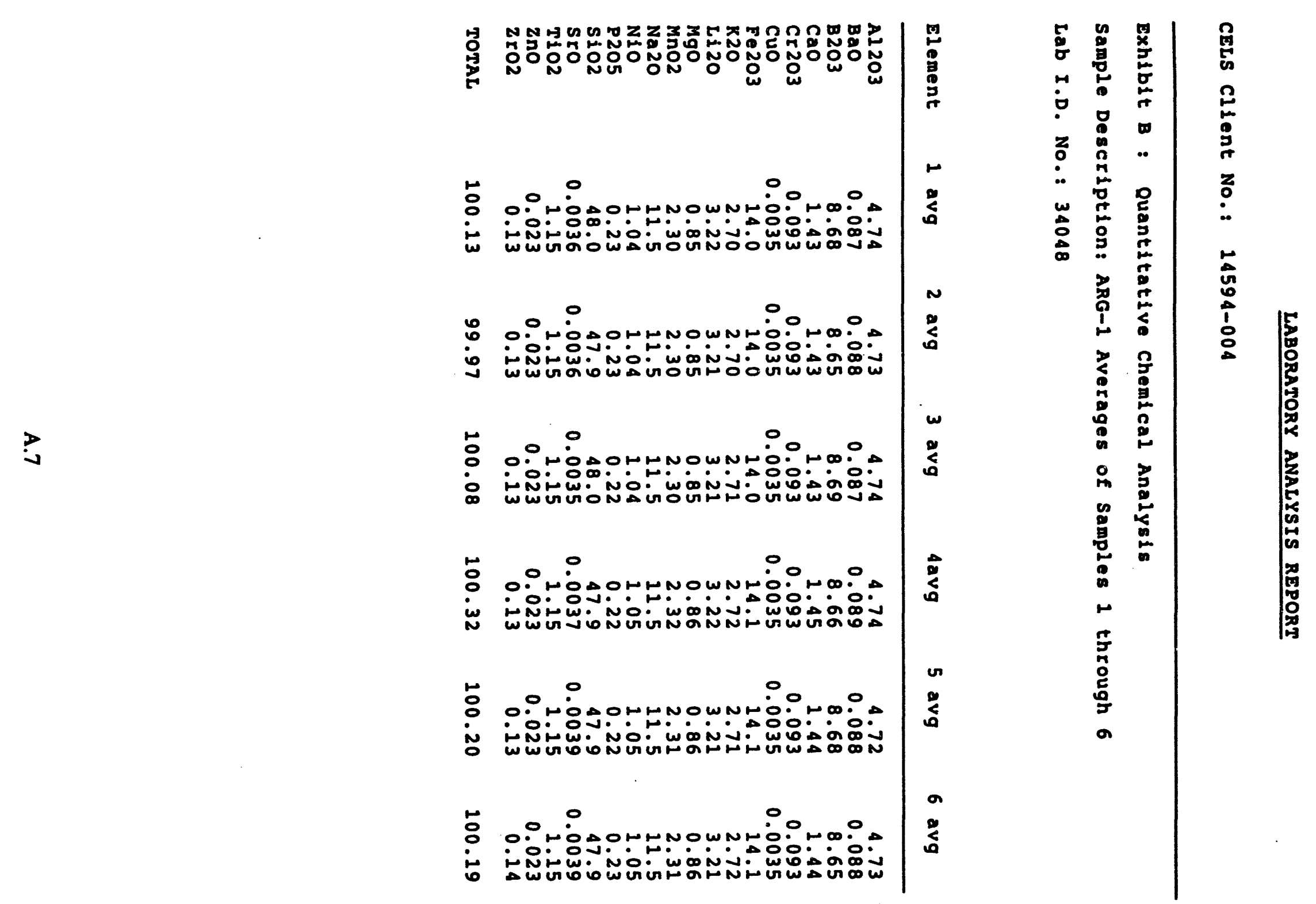
CELS Client No.: 14594-004

Exhibit B : Quantitative Chemical Analysis

Sample Description: ARG-1 stastical Data

Lab I.D. No.: 34048

\begin{tabular}{lrrrr} 
Element & Target & Mean & Std Dev & RSD \\
\hline Al203 & 4.53 & 4.73 & 0.022 & 0.5 \\
BaO & 0.04 & 0.088 & 0.001 & 0.8 \\
B203 & 8.39 & 8.67 & 0.040 & 0.5 \\
CaO & 1.53 & 1.43 & 0.009 & 0.6 \\
Cr203 & 0.096 & 0.093 & 0.001 & 0.8 \\
CuO & 0.008 & 0.004 & 0.000 & 2.6 \\
Fe203 & 13.85 & 14.0 & 0.073 & 0.5 \\
K20 & 2.59 & 2.71 & 0.016 & 0.6 \\
L120 & 3.26 & 3.21 & 0.015 & 0.5 \\
MgO & 0.85 & 0.86 & 0.005 & 0.6 \\
MnO2 & 2.39 & 2.31 & 0.012 & 0.5 \\
Na20 & 11.36 & 11.5 & 0.023 & 0.2 \\
N10 & 1.03 & 1.05 & 0.006 & 0.6 \\
P205 & 0.25 & 0.22 & 0.011 & 4.8 \\
S102 & 48.6 & 47.9 & 0.157 & 0.3 \\
SrO & 0.006 & 0.0037 & 0.000 & 4.4 \\
T102 & 1.12 & 1.15 & 0.007 & 0.6 \\
ZnO & 0.014 & 0.02 & 0.000 & 0.7 \\
Zr02 & 0.128 & 0.13 & 0.005 & 3.6 \\
TOTAL & 100.00 & 100.15 & &
\end{tabular}

A.8 


\section{Distribution}

No. of

Copies

Onsite

12 DOE/Office of Scientific and

Technical Information

Linda P. Adams

Corning, Inc. - CELS

HP-ME-03-078

Corning, NY 14845

David P. Baldwin

Ames Laboratory

8 Spedding Hall, ISU

Ames, IA 50011

James E. Barefield

Los Alamos National Laboratory

MS J567

Los Alamos, NM 87545

John Bates

Argonne National Laboratory

Building 205

9700 South Cass Ave.

Argonne, IL 60439

Ellyn S. Beary

National Institute of Standards

and Technology

Building 222, Room A323,

Mail No. A341

Gaithersburg, MD 20899

David R. Best

Westinghouse Savannah River Company

704-IT, Room 231

Aiken, SC 29803
No. of

Copies

Ned E. Bibler

Westinghouse Savannah River Company

P.O. Box 616

Aiken, SC 29802

W. T. (Bill) Boyce

Westinghouse Savannah River Company

P.O. Box 616, Building 773A

Aiken, SC 29802

Paul Briggs

U.S. Geological Survey

P.O. Box 25046

Denver, CO 80225-0046

Ronaid B. Chessmore

RUST Geotech Inc.

P.O. Box 14000

Grand Junction, CO 81502

Charles (Chuck) J. Coleman

Westinghouse Savannah River Company

Building 773-A, Room 427

Aiken, SC 29808

Jeffrey Crain

Argonne National Laboratory

Building 200

9700 South Cass Avenue

Argonne, IL 60439

Ray Dewberry

Westinghouse Savannah River Company

Savannah River Technological Center

Building 773-A

Aiken, SC 29802

Distr.1 
PNL-8992

No. of Copies

Douglas Duckworth

Oak Ridge National Laboratory

P.O. Box 2008

Bldg. 5505, MS-6375

Oak Ridge, TN 37831-6375

Richard Ediger

Perkin Elmer Corporation

761 Main Avenue

Norwalk, CT 06859

Debbie Figg

Los Alamos National Laboratory

CLS-1 MS G-740

Los Alamos, NM 87545

Sabrina S. Fu

Catholic University of America

Vitreous State Laboratory

620 Michigan Avenue, NE

Washington, DC 20064

Douglas Goforth

Corning, Inc. - CELS

HP-ME-03-070

Corning, NY 14831

Meiling Gong

Argonne National Laboratory

Building 205

9700 South Cass Avenue

Argonne, IL 60439-4837

Rob Henry

Fisons Instruments

P.O. Box 20460

Boulder, CO 80308-3460

Jim Hojnicki

Monarch Analytical Laboratories

1365 Tomahawk Drive

Maumee, OH 43537
No. of

Copies

Mark Hollenbach

RUST Geotech Inc.

P.O. Box 14000

Grand Junction, CO 81502

Ben Hunter

Westinghouse Idaho Nuclear Corporation

P.O. Box 4000

Idaho Falls, ID 83403

Robert Jakubik

BDM Federal Inc.

20300 Century Boulevard, Suite 100

Germantown, MD 20874

Carol M. Jantzen

Savannah River Laboratory

P.O. Box 616, MS 773-A

Aiken, SC 29802

John Keller

Oak Ridge National Laboratory

P.O. Box 2008

Bldg. 2026, MS-6043

Oak Ridge, TN 37831-6043

W. Frank Kinard

College of Charleston

Department of Chemistry

66 George Street

Charleston, SC 29424

Paul Lamothe

U.S. Geological Survey

P.O. Box 25046

Denver, CO 80225-0046

Gordon Lien

Westinghouse Savannah River Company

P.O. Box 616, Building 704-28S

Aiken, SC 29802 
No. of

Copies

David A. Loop

West Valley Nuclear Services

P.O. Box 191, MS-307

West Valley, NY 14171-0191

John Lyttle

RUST Geotech Inc.

P.O. Box 14000

Grand Junction, CO 81502

Hersh K. Manaktala

Southwest Research Institute

P.O. Drawer 28510

San Antonio, TX 87545

John H. Marlow

West Valley Nuclear Services

P.O. Box 191, MS 307

West Valley, NY 14171-0191

Al Meier

U.S. Geological Survey

P.O. Box 25046

Denver, CO 80225-0046

Roy Morrow

Martin Marietta Energy Systems

P.O. Box 2003, M.S. 7279

Oak Ridge, TN 37830

Jose A. Olivares

Los Alamos National Laboratory

MS J514

Los Alamos, NM 87545

Ronald A. Palmer

West Valley Nuclear Services

P.O. Box 191

West Valley, NY 14171-0191

M. John Plodinec

Savannah River Laboratory

P.O. Box 616, MS 773-A

Aiken, SC 29802
No. of

Copies

Tim A. Policke

Westinghouse Savannah River Company

704-IT, TNX

Aiken, SC 29803

James A. Poppiti

U.S. Department of Energy

Route EM-563

12800 Middlebrook Road

Germantown, MD 20874

Larry Robinson

Oak Ridge National Laboratory

P.O. Box 2008

Bldg. 4500 South, MS-6128

Oak Ridge, TN 37831-6128

Roxie Ross

IT Analytical Services

2800 George Washington Way

Richland, WA 99352

Price Russ

Lawrence Livermore National Laboratory

7000 East Avenue, Building 222,

M.S. L-310

Livermore, CA 94550

Kim Shirley

U.S. Department of Energy

785 DOE Place, MS 4149

Idaho Falls, ID 83401

Ron Spencer

Westinghouse Savannah River Company

P.O. Box 616, Building 704-28S

Aiken, SC 29802

Joe Taggart

U.S. Geological Survey

P.O. Box 25046, M.S. 973

Denver, CO 80225-0046 
No. of

Copies

Mary Verwolf

Idaho National Engineering Laboratory EG\&G Idaho, Inc.

P.O. Box 1625

Idaho Falls, ID 83415-4107

Charles N. Wilson

Westinghouse Hanford Company

P.O. Box 1970, MSIN G6-08

Richland, WA 99352

Stephen Wilson

U.S. Geological Survey

P.O. Box 25046, MS 973

Denver, CO 80225-0046

Steven B. Wyrick

Science Application

International Corporation

555 Quince Orchard Road, Suite 500

Gaithersburg, MD 20878

Dan Zamzow

Ames Laboratory

8 Spedding Hall, ISU

Ames, IA 50011

\section{Foreign}

\section{Kerry Burns}

AECL, Chalk River Laboratory

General Chemistry

Chalk River, Ontario Canada KOJ 1 JO
No. of

Copies

Onsite

\section{RL/Richland Operations Ofrice}

\section{Westinghouse Hanford Company}

Steve Kelly, G6-08

John J. McCown, B2-23

Charles N. Wilson, G6-08

32 Pacific Northwest Laboratory

J. Leland (Lee) Daniel, P7-27

Dennis L. Eggett, K7-34

Frank Hara, P7-43

Steven C. Marschman, P7-18

Gary Mong, P8-08

Kathy M. Otson, P7-14

Karl Pool, P8-44

Gary L. Smith, P7-14 (15)

Harry D. Smith, P7-14

Monty R. Smith, P8-08

Mike Urie, P7-22

Eric J. Wyse, P8-08

Publishing Coordination

Technical Report Files (5) 

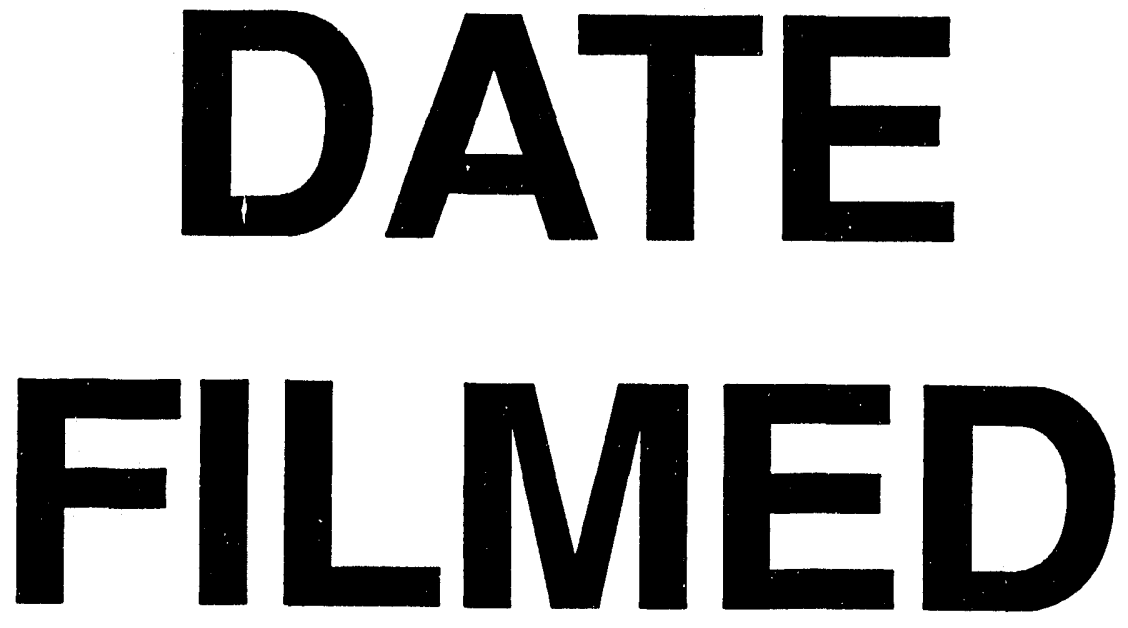

$6 / 22 / 94$
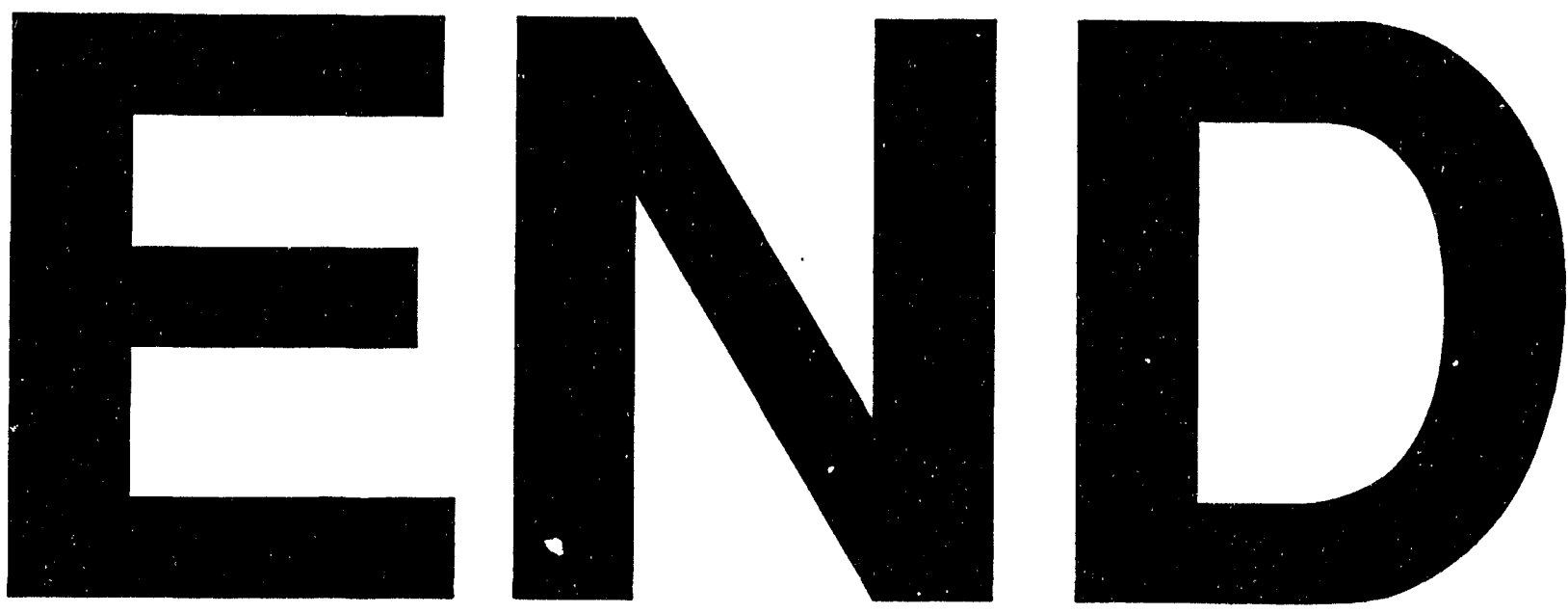
